\title{
THE ROLE OF FINANCIAL SUPPORT FOR THE PERFORMANCE AND SURVIVAL OF MICRO-ENTERPRISES
}

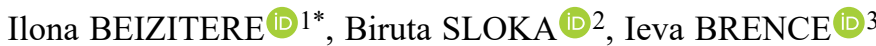 \\ ${ }^{1}$ Analytical Service, Parliament of the Republic of Latvia, Jekaba iela 11, LV1811 Riga, Latvia \\ ${ }^{2}$ Faculty of Business, Management and Economics, University of Latvia, \\ Aspazijas bulv. 5, LV1050 Riga, Latvia \\ ${ }^{3}$ Latvian Academy of Sciences, Akademijas square 1, LV1050 Riga, Latvia
}

Received 28 February 2021; accepted 01 April 2021

\begin{abstract}
Purpose - to examine the Latvian micro-enterprises having indicated the external financing as an important factor for their development.

Research methodology - the results of the ad hoc survey (WAPI) on companies registered in Latvia in nationally defined sectors are used. Valid responses were received from 2.511 companies, of which 1.879 were micro-enterprises, the results were processed by using the SPSS programme.

Findings - micro-enterprises that have not received the necessary external financing in previous years were less sustainable in the later period. Of the liquidated micro-enterprises examined, 16\% were closed in 2020.

Research limitations - the study highlights the impact of the availability of finance factor on the survival of micro-enterprises.

Practical implications - the findings are useful for business support policy makers to identify preventative measures to ensure the resilience of micro-enterprises in times of economic turmoil when the spread of the Covid-19 has affected economy.

Originality/Value - although scientific research on the need for financial support for companies has already been conducted in recent years, our study emphasizes the importance of access to finance for micro-enterprises.
\end{abstract}

Keywords: banks, finance institutions, firm performance, micro-enterprises, micro-entreprise financing.

JEL Classification: G21, G23, G28, L25, L29.

Conference topic: Contemporary Financial Management.

\section{Introduction}

Small and Medium Enterprises (SMEs) are recognized all over the world as backbone of modern economies because they make major contributions to global economic growth and sustainable development through employment generation, poverty alleviation, wealth creation and food security (Peter et al., 2018). According to the World Trade Report (World Trade Organization, 2016) in developed countries, SMEs account for more than $90 \%$ of enterprises, contributing $60-70 \%$ of employment and $55 \%$ of gross domestic product (GDP). In turn, the OECD report showed that SMEs could provide up to $45 \%$ of total employment and 33\% of GDP in emerging countries (Organisation for Economic Co-operation and Development [OECD], 2017). According to the findings of the Small Business Administration 78.6\% of newly established businesses between 2005 and 2017 survived one year (Small Business Administration [SBA], 2018). Unfortunately, only about half of these companies have a business life of five years. In turn, only one in three small businesses typically reaches ten years of operation. Although the data presented here refer to the United States, other studies show a similar trend worldwide (Erskine \& Yong, 2020).

The aim of our study is to find out the importance of financial support for the development of micro-enterprises from the point of view of entrepreneurs themselves and the reaction of financial employers, promoting the availability of financial support for micro-enterprises, which is the largest share of SMEs in Latvia. The study focuses on the

*E-mail: ilona.beizitere@gmail.com

(C) 2021 Authors. Published by Vilnius Gediminas Technical University. This is an open-access article distributed under the terms of the Creative Commons Attribution (http://creativecommons.org/licenses/by/4.0/) License, which permits unrestricted use, distribution, and reproduction in any medium, provided the original author and source are credited. 
availability of financial support in Latvia for micro-enterprises in accordance with the European classification system (European Commission, 2003). Micro-enterprises make up 94\% of all economically active enterprises in Latvia (Central Statistical Bureau of Latvia, 2020).

According to the OECD (2020), the SME lending sector in Latvia is dominated by banking sector lending, which accounted for $74 \%$ (at the end of 2018) of total lending to local non-financial corporations (NFCs). Although loans to the SME banking sector decreased by $8.3 \%$ in 2018 , excluding one-off effects, the volume of loans to SMEs did not change significantly (-1.0\% year-on-year). In 2018, new loans (flow) to SMEs were slightly higher than in 2017 (3.9\%). In 2018, the new lending (flow) to SMEs was slightly higher than in 2017 (by 3.9\%). Over the period covered by the OECD assessment, the overall economic environment remained favorable, supported by rising investment and domestic demand. Risk and growth capital in 2017 increased from 79.4 million euros to 120 million euros. In 2018, 3 new acceleration funds were introduced to the market in addition to several seed, start-up and growth capital funds to promote the development of venture capital investments. Currently, the distribution of state support programs continues through the JSC Development Financial Institution Altum (ALTUM), which offers assistance and financial instruments to various target groups, including micro enterprises. The government facilitates access to finance (through a microcredit, start-up and loan program) for companies that lack the financial credibility (collateral, net worth, cash flow and credit history) needed to access finance from commercial banks or private investors (ALTUM, n.d.). ALTUM's task is to implement state aid programs to compensate for market failures that cannot be remedied by private financial institutions.

The results of a business survey are used in this article. A computer-assisted web interview (CAWI) questionnaire was sent to Latvian companies with publicly available e-mail addresses in the period from January 10, 2018 to January 25,2018 . The request to complete the questionnaire was addressed to the person in charge of corporate finance. The target audience was all Latvian companies operating in sectors eligible for state aid. The entire studied segment included all active enterprises registered in the Latvian Register of Enterprises with 11 defined NACE codes, i.e. a total of 32308 enterprises. To improve representativeness, data were evaluated by industry share. The ad hoc online business survey (WAPI) asked entrepreneurs to disclose their sources of funding for the three-year period 2015-2017. Valid responses were received from 2511 companies, of which 1879 were micro-enterprises. Respondents identified the diversity of financial sources and answered whether they needed additional funding for their performance in the near future. Previous study based on this survey had shown alarming results: according to the data processed by the SPSS, micro-enterprises most often chose bank financing (short-term and long-term - 11\%) among many sources, while only $4 \%$ of respondents used loans from the financial institution ALTUM (which is the principal intermediary of state aid in Latvia). In addition, the study showed that although almost half of the micro-enterprises needed new or additional funding, a large part of them relied solely on internal finances (Beizitere et al., 2020b). This article provides an in-depth analysis of the reasons for refusals by financial institutions from the point of view of entrepreneurs. In order to find out the impact of the financial shortage in the previous years on the future operation of micro-enterprises, the sample of micro-enterprises from the survey was additionally analysed. This group $(n=667)$ showed that access to finance has been an important factor for their growth. Among the liquidated companies, most relied on internal financing, but only a few had received a loan from a bank or finances with public support. Of the liquidated micro-enterprises examined, only 16\% closed down in 2020 (which may have been affected by the business restrictions imposed by the coronavirus Covid-19).

\section{Theoretical findings}

Academic research is devoting a lot of attention on microenterprise financing including important aspects of several stages of company development (Prijadi et al., 2020) and on financing of microenterprises (Hartungi, 2007). SMEs are a powerful economic engine in many European countries (Moya-Martinez \& Pozo-Rubio, 2020), substantial contributors to employment and to the GDP growth in many countries (Martinez et al., 2020), SMEs and employment creation are very important for countries all over the world (Herr \& Nettekoven, 2017). Political decisions are often important for business support (Daugèliene, 2016). Small business is characterised by flexibility, agility, the ability to respond quickly to the slightest changes in economic environment and market requirements (Verovska \& Zujeva, 2019). SMEs are not only an important source of employment; they can also become a source of innovation and increased productivity (Herr \& Nettekoven, 2017). A very useful material for different stakeholders is publication by the Organisation for Economic Co-operation and Development, for example, "Financing SMEs and Entrepreneurs 2020: An OECD Scoreboard" which provides a comprehensive framework for policy makers and other stakeholders to monitor access to finance by SMEs and entrepreneurs (OECD, 2020).

Finance is the elixir that assists in the formation of new businesses, allows businesses to take advantage of opportunities to grow, employ local workers, and in turn support other businesses and local, state and federal government through the remittance of income taxes (Duff, 2019), the extent to which enterprises have access to finance is an important determinant (Doove et al., 2014). For their development, also the trade credit had a large positive impact 
on firm survival, such that a one standard deviation increase in trade credit results in a $21 \%$ decrease in the likelihood of distress (McGuinnessa et al., 2018). The availability of funding is one of the key problems in the small and medium-sized business not only in Europe but also all over the world economic space (Rupeika-Apoga \& Solovjova, 2016).

The importance of non-traditional, alternative/innovative financing is gaining recognition in both developed and emerging economies throughout the world. SMEs' financing in Europe remains primarily bank based, in spite of many policies proposed to develop alternative financing instruments (e.g., adopting directives on venture capital, improving the transparency and visibility of SMEs on capital markets, etc.) (Rupeika-Apoga \& Saksonova, 2018), several specific aspects of micro-enterprise financing are also recognised as specific for green economics (Rouf, 2012). Access to finance has been identified as the most important problem that SMEs face. Lack of access to financing is consistently cited by SMEs as one of the main barriers to growth (Harelimana, 2017), however financial support is a determinant of the success of small, medium and micro enterprises (Rungani \& Potgieter, 2018). Government support programmes creates important contextual conditions that facilitate the capacity of SMEs to contribute to development through the production of goods and services and the creation of employment (Peter et al., 2018), and are seen as important tools for enhancing the performance of SMEs.

SME financing in Europe is not homogeneous but that different financing patterns exist. The cluster analysis identifies six distinct SME financing types: mixed-financed SMEs, state-subsidised SMEs, debt-financed SMEs, flexible-debt-financed SMEs, trade-financed SMEs and internally financed SMEs. These SME financing types differ according to the number of financing instruments used and the combinations thereof. Furthermore, the types of financing available to SMEs can be profiled according to their firm-, product-, industry- and country-specific characteristics (Moritz et al., 2016). Despite enormous effort by government to foster growth and development in the SMEs sector through various support programmes, the rising failure and underperformance of the SMEs sector suggest a contrary effect (Peter et al., 2018). A crucial element in the development of the SME sector is access to finance for the creation, survival and growth of small businesses. Many governments in developed countries design programs to improve the competitiveness of the local firms.

The main goal of government financial support is to promote business in order to accelerate economic growth (Hartšenko \& Sauga, 2013). Controlling for family funding, bank financing, equity of business angels and venture capitalists, industry, size, as well as entrepreneur's characteristics, the results reveal that government guarantees and government equity have a direct effect on new firms' competitive advantage and only an indirect impact on performance (Pergelova \& Angulo-Ruiz, 2014). A study (Bertoni et al., 2019) concluded that loans guaranteed by the European Investment Fund had a positive effect on companies' assets, sales and employment. Businesses also had a better chance of survival and less chance of going bankrupt. In addition, the positive impact was stronger for new and smaller companies, which generally do not have a good credit history. There was a greater positive impact on those operating in the service sector than in manufacturing, but the impact did not seem to be higher in high-tech and knowledge-intensive sectors than in low-tech sectors.

In general, the strategic use of financial instruments, such as loans and investments, is key to the success of every business. Financial trends also define the state of the economy on a global level, so central banks can plan appropriate monetary policies (Duff, 2019). Main findings show that alternative financial service providers are competing and often outcompeting the traditional ones at high speed. Conducted empirical analysis shows the most available financing sources except banking products are Friends and Family and different state (including European Union grants) support programmes, Venture Capital and Business Angels (Rupeika-Apoga \& Saksonova, 2018). More and more importance is paid to security aspects (Davidavičienė et al., 2019; Raudeliūnienė et al., 2014).

In 2014, institutions of public financial support, non-bank credit institutions and Venture Capital funds increased their share in the micro-enterprises financing (and in the financing of all enterprises). The greatest changes in the structure of the micro-enterprises financing occurred due to the aid granted to small businesses by institutions of public financial support (Prohorovs \& Beizitere, 2015) and the trend is continuing now. Other research works emphasize that probability to innovate increases when firms use internal financing and grants. The same applies when funds come from family and friends, while not found conclusive evidence for bank loans (Aiello et al., 2020). Important aspects are also marketing aspects (Batraga et al., 2018) which also often influence decisions on the financing for company.

Several reasons have been identified for SMEs to fail ultimately. Among them, frequently mentioned explanations are financial management skills and performance (Erskine \& Yong, 2020), also lack of financial literacy of micro, small and medium-sized enterprises owners/managers is often mentioned among the reasons of their financial exclusion (Beizitere, 2018; Saksonova \& Papiashvili, 2021). Research from Korea proves that "financial resources from the Korean government indeed help Korean SMEs survive, but do not necessarily help them achieve higher annual assets and sales growth" (Park et al., 2020). However, when government-based diagnostic and support services are combined with public loan financing, they prove to be effective in enhancing the Korean SMEs' annual assets and sales growth (Park et al., 2020). 


\section{Empirical research results and discussion}

A survey of the companies was conducted at the beginning of 2018 to find out the possibilities of micro-enterprises in Latvia to obtain financing and, among other things, to identify the most frequently used reasons for refusal. A study conducted so far, based on the above survey, has shown companies have indicated access to finance among the most important 13 factors limiting business activity (Beizitere et al., 2020a). At the same time, external financing was not widely used among micro-enterprises, as according to the survey data processed, micro-enterprises still prefer internal financing (64\%) among many sources, whereas only $11 \%$ of the respondents used public funding (Beizitere et al., 2020b).

An in-depth study was carried out to find out the discrepancy between financing opportunities in Latvia, including the relatively large financial offer of European Union funds, and the reluctance of micro-enterprises to obtain it. The financing needs of entrepreneurs on the one hand, and the reasons for rejection of financing provided by financiers on the other hand are demonstrated below. The survey consisted of questions, many of which required them to be answered on a scale of 1 to 5 (where 1-restricted but 5-unrestricted).

The survey data processing, reability tests have been done by the data analysis programme in the SPSS environment and report a high Cronbach's alpha coefficient (see Table 1).

The distribution of company's responses according to their needs for additional (external) financing to perform company's activities or to realize the idea is included in the Table 2.

Research results indicate that $43.4 \%$ of micro-enterprises in Latvia do not need additional (external) financing they are ready to reach their company development by themselves, $38.1 \%$ of the micro-enterprises in Latvia need additional (external) financing.

There are several ways in possible getting of external financing including the state-owned financial institution ALTUM that offers public support financial instruments such as loans on terms that are easier to enforce than bank terms, various guarantees, including to guarantee the repayment of bank loans, and venture capital funding for fast-growing and innovative micro-enterprises (ALTUM, n.d.). Demand for financing differs by regions of Latvia.

Research results indicate that there are different needs for additional financing by company location. Distribution of company responses on needs for additional (external) financing to perform company activities by regions of Latvia is included in the Figure 1.

Research results indicate that in most of the cases micro-enterprises in Latvia do not need additional (external) financing in more developed regions - Riga, but smaller number of companies - in less developed region Latgale. Many of them are ready to reach their company development by themselves (see Figure 1).

Looking in more detail at the views of micro-enterprises, given the number of employees, additional external funding is needed more for those with 5-9 employees to achieve the company's development (see Table 3).

Many companies has applied to different institutions for external financing including to the state-owned development finance institution ALTUM but many of them were refused funding. The distribution of the refusal aspects of micro-enterprise financing is reflected in the Table 4.

Research data in Table 4 indicate that most of financing refuse reason was insufficient cash flow, followed insufficient collateral and insufficient own capital. Smaller numbers of refuse for financing were related to problems in the company's industry and negative owner reputation or credit history.

Table 1. Data reability tests by SPSS (source: authors' constructions)

\begin{tabular}{|c|c|c|c|}
\hline \multicolumn{4}{|c|}{ Case processing summary } \\
\hline \multirow{3}{*}{ Cases } & Valid & 1879 & 100.0 \\
\cline { 2 - 4 } & Excluded $^{\mathrm{a}}$ & 0 & 0 \\
\cline { 2 - 4 } & Total & 1879 & 100.0 \\
\hline
\end{tabular}

\begin{tabular}{|c|c|}
\hline \multicolumn{2}{|c|}{ Reliability statistics } \\
\hline Cronbach's Alpha & N of items \\
\hline 0.823 & 13 \\
\hline
\end{tabular}

Note: ${ }^{\text {a }}$ - listwise deletion based on all variables in the procedure.

Table 2. Distribution of responses on the question "Does your company need additional (external) financing to perform company activities?” (source: survey of micro-enterprise entrepreneurs, $n=1879$ )

\begin{tabular}{|c|c|c|c|c|}
\hline Answers of respondents & Frequency & Percent & Valid percent & Cumulative percent \\
\hline Yes & 716 & 38.1 & 38.1 & 38.1 \\
\hline No & 816 & 43.4 & 43.4 & 81.5 \\
\hline Hard to say & 347 & 18.5 & 18.5 & 100.0 \\
\hline Total & 1879 & 100.0 & 100.0 & \\
\hline
\end{tabular}




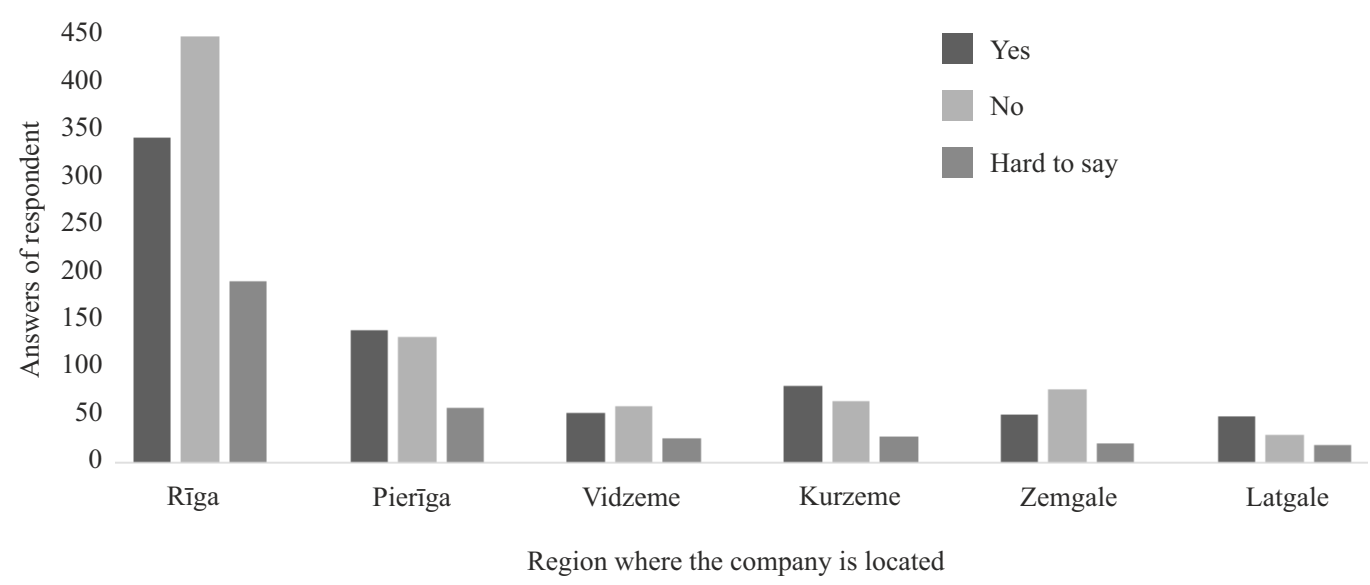

Figure 1. Distribution of responses on the question "Does your company need additional (external) financing to perform company activities?" by regions of Latvia (source: survey of micro-enterprise entrepreneurs, $n=1879$ )

Table 3. Distribution of responses on the question "Does your company need additional (external) financing to perform company activities?" by shareof employees in percent (source: survey of micro-enterprise entrepreneurs, $n=1879$ )

\begin{tabular}{|c|c|c|c|}
\hline \multirow{2}{*}{ Answers of respondents } & \multicolumn{2}{|c|}{ Share (in \%) of companies by responses by employees in the company } & \multirow{2}{*}{$\begin{array}{c}\text { Total } \\
(n=1879)\end{array}$} \\
\cline { 2 - 4 } & $1-4$ employees $\left(n_{\text {ref }}=1413\right)$ & $5-9$ employees $\left(n_{\text {ref }}=466\right)$ & 38 \\
\hline Yes & 36 & 46 & 43 \\
\hline No & 45 & 38 & 18 \\
\hline Hard to say & 19 & 17 & 17 \\
\hline
\end{tabular}

Table 4. Reasons for refusal to finance micro-enterprises (source: survey of micro-enterprise entrepreneurs, $n=1879 ; n_{\text {ref }}=171$ )

\begin{tabular}{|l|c|c|c|}
\hline Reason for refusal to finance & Number & Share from respondents (\%) & Share from refuse (\%) \\
\hline Insufficient cash flow & 57 & 3 & 33.3 \\
\hline Insufficient collateral & 48 & 2.6 & 28.1 \\
\hline Insufficient own capital & 45 & 2,4 & 26.3 \\
\hline Insufficient cost-benefit ratio & 22 & 1.2 & 12.9 \\
\hline Lack of owner guarantee & 18 & 1 & 10.5 \\
\hline Start-up company or till 5 years & 16 & 0.9 & 7.4 \\
\hline Concerns about the viability of the project & 13 & 0.7 & 5.6 \\
\hline Insufficient self-financing for the project & 11 & 0.4 & 5.3 \\
\hline Negative owner reputation or credit history & 9 & 0.5 & 3.5 \\
\hline Problems in the company's industry & 6 & 0.3 & 12.9 \\
\hline Other reason & 22 & 1.2 & 16.4 \\
\hline Hard to say & 28 & 1.5 & \\
\hline
\end{tabular}

Other reasons for a bank or leasing company to refuse to provide financing mentioned by number of entrepreneurs are given in the Table 5. Among the answers provided, there are those that describe the entrepreneur's emotional attitude towards refusal, for example, those that characterize the behavior of an ALTUM employee. However, most of these answers could be reduced to some of the answers listed in Table 4. For example, answer Previous year's balance sheet with a “-” sign, Previous year's deficit, The micro-enterprise declaration was not sufficient proof of income and The company has been operating at a loss for the past 2 years correspond to the general respond Insufficient cost-benefit ratio. The attitude of banks or other financial institutions in refraining from lending to a micro-enterprise would probably be understandable here. In turn, answers Lack of pledge and Inadequate loan percent rate offered refer to respond Insufficient collateral. Obviously, the company had to turn to the financial institution ALTUM and not to the bank to deal with the problem of insufficient collateral.

In order to find out the impact of the financial shortage in the previous years on the future operation of micro-enterprises, the sample of micro-enterprises from the survey was additionally analysed. 
Table 5. Other reasons for a bank or leasing company to refuse to provide financing mentioned by number of entrepreneurs (source: survey of micro-enterprise entrepreneurs, $n=1879 ; n_{\text {ref }}=22$ )

\begin{tabular}{|c|c|c|}
\hline \multirow{2}{*}{ Responses } & \multicolumn{2}{|c|}{$\begin{array}{l}\text { Number of employees in the } \\
\text { company }\end{array}$} \\
\hline & $1-4$ & $5-9$ \\
\hline The product (electronics) is in the idea stage & 1 & \\
\hline $\begin{array}{l}\text { The representative of the ALTUM replied: "You have enough money for yourself! Capitalia } \\
\text { (a financial institution entrusted with granting loans from ALTUM resources) referred to the } \\
\text { recommendation not to give money according to ALTUM data!" }\end{array}$ & 1 & \\
\hline Previous year's balance sheet with a “-_" sign & 1 & \\
\hline Previous year's deficit & 1 & \\
\hline The micro-enterprise declaration was not sufficient proof of income & 1 & \\
\hline Insufficient number of customers & 1 & \\
\hline I offered an application that performs lunar cycle calculations using astrological methods & 1 & \\
\hline Inadequate loan percent rate offered & 1 & \\
\hline Incorrect rejection, such as typos, dots, length marks, etc. & 1 & \\
\hline The company has been operating at a loss for the past 2 years & 1 & \\
\hline Negative attitude of ALTUM employees towards the owner & 1 & \\
\hline The company's field of activity is construction services & 1 & \\
\hline The Latvian state is not interested in the development of small business & 1 & \\
\hline Frequent reason for refusal that the company is older than 5 years & 1 & \\
\hline Tax debt & 3 & 1 \\
\hline Lack of pledge & & 1 \\
\hline Illiquid equipment & & 1 \\
\hline $\begin{array}{l}\text { In the opinion of bank "financial analysts" will not be able to return, because the cash flow } \\
\text { was not ideal in the last year }\end{array}$ & & 1 \\
\hline Does not support the tourism industry & & 1 \\
\hline Total number of responses from entrepreneurs of micro-enterprises & 17 & 5 \\
\hline
\end{tabular}

A small sample was selected, consisting of micro-enterprises, which answered the question: "What factors significantly limit the growth of your representative's business?" The micro-enterprises that indicated that access to finance has the most significant impact on them were examined. Growth impediments were rated on a scale of 1 to 5 . Micro-enterprises that responded to the question as "almost restrictive" (4) and "restrict" (5) are considered to be limited. The total number of micro-enterprises whose access to finance factor limits their growth was 667 or $35 \%$ of all surveyed micro-enterprises $(n=1879)$.

This group $(n=667)$ showed that access to finance had been an important factor for their growth. In examining the viability of post-business survey, it was found that according to the data of the Latvian Register of Enterprises, some companies ( $9 \%$ of the selection) had problems with continuing their business (see Table 6 ).

Among the liquidated companies, most relied on internal financing, but only four of micro-enterprises had received a short-term financing or a long-term loan from a bank and five of them had obtained finances with public support. Of the liquidated micro-enterprises examined, only 16\% closed down in 2020 (which may have been affected by the business restrictions imposed by the coronavirus Covid-19). It should be emphasized that the majority (77\%) of micro-enterprises that were forced to close down had 1-4 employees.

Table 6. Status of the company on 31.01.2021 (source: Latvian Register of Enterprises, survey of micro-enterprise entrepreneurs, $n=667$ )

\begin{tabular}{|l|c|}
\hline Status of the company & Number of micro-enterprises \\
\hline Active & 607 \\
\hline Liquidated & 49 \\
\hline Suspension of economic activity & 6 \\
\hline Insolvency proceedings & 4 \\
\hline Legal protection process & 1 \\
\hline
\end{tabular}




\section{Conclusions}

Academic research has shown that there are several ways to get support for company financing, and they analyze widely the ways to overcome problems with company financing by finding various innovative solutions.

In previous years, less than half (38\%) of Latvia's micro-enterprises needed additional external financing for development. Among them, there are fewer (36\%) relatively small micro-enterprises with one to four employees that need additional funding.

Overall, a small proportion (9\%) of micro-enterprises for which access to finance was essential for their operations had problems in continuing their business in the period following the survey of enterprises. However, among these companies, a large part of the smallest micro-enterprises (considering the number of employees 1-4) were forced to close down their business in 2018-2020.

Refusal of financing was mainly due to insufficient cash flow, insufficient collateral and insufficient own capital. The lower number of refusals was related to problems in the company's industry and negative owner reputation or credit history.

The results show that financial donors have been very cautious in financing micro-enterprises. It is possible that many micro-enterprises could avoid certain types of refusals by turning to the financial institution ALTUM. ALTUM offers programs with public financial support, for example, in cases with insufficient collateral, or in the start-up phase when financial indicators are not sufficiently stable.

Despite Latvia's policy to improve access to public finances, including support for micro-enterprises, there have been few targeted measures and their opportunities have not always met their intended targets. In the past, there has been no popular public supported financing instruments among micro-enterprises, although the terms of financing programs offered by the government have been less strict than those for bank lending.

\section{Acknowledgements}

We are grateful to the Marketing and Public Opinion Research Center (SKDS) for assistance in conducting the survey of entrepreneurs.

\section{Funding}

The research was supported by the National Research Program "INTERFRAME-LV".

\section{References}

Aiello, F., Bonanno, G., \& Ross, S. P. S. (2020). How firms finance innovation. Further empirics from European SMEs. Metroeconomica, 71(4), 689-714. https://doi.org/10.1111/meca.12298

ALTUM. (n.d.). What we are. https://www.altum.lv/en/about-altum/what-we-are/

Batraga, A., Salkovska, J., Legzdina, A., Rukers, I., \& Bormane, S. (2018). Consumer behavior af-fecting factors leading to increased competitiveness during holiday season. Economic Science for Rural Development, 48, 329-337. https://doi.org/10.22616/ESRD.2018.102

Beizitere, I. (2018, May 10-12). Is availability of financial instruments a challenge for micro enterprises? In Proceedings of the 10th International Scientific Conference "New Challenges of Economic and Business Development - 2018: Productivity and Economic Growth” (pp. 30-41), Riga, Latvia. University of Latvia. https://www.bvef.lu.lv/fileadmin/user_upload/lu_portal/ projekti/bvef/konferences/evf_conf2018/Proceedings_2018.pdf

Beizitere, I., Sloka, B., \& Brence, I. (2020a). Restrictive factors for micro-company growth in Latvia. European Integration Studies, 13, 172-184. https://doi.org/10.5755/j01.eis.1.14.26567

Beizitere, I., Brence, I., \& Sloka, B. (2020b). Public financing support options to micro-enterprises for innovation. European Integration Studies, 13, 238-248. https://doi.org/10.5755/j01.eis.1.14.26569

Bertoni, F., Brault, J., Colombo, M. G., \& Quas, A. (2019, February). Econometric study on the impact of EU loan guarantee financial instruments on growth and jobs of SMEs (EIF Working Paper 2019/54). EIF Research \& Market Analysis.

Central Statistical Bureau of Latvia. (2020). SRG030. Economically active enterprises of market sector in statistical regions, cities and counties by size group according to the number of employees and main economic activity (NACE Rev. 2). http://data1.csb. gov.lv/pxweb/en/uzn/uzn_01_skaits/?rxid=d8284c56-0641-451c-8b70-b6297b58f464\&tablelist=true

Daugèlienè, R. (2016). EU's political actions for the enhancement of macroeconomic stability in con-frontation with great economic recession. Entrepreneurship, Business and Economics, 2(3-2), 647-663. https://doi.org/10.1007/978-3-319-27573-4_42

Davidavičienė, V., Raudeliūnienè, J., Tvaronavičienè, M., \& Kaušinis, J. (2019). The importance of security aspects in consumer preferences in electronic environment. Journal of Security and Sustainability, 8(3), 399-411.

Doove, S., Gibcus, P., Kwaak, T., Smit, L., \& Span, T. (2014). Survey on the Access to Finance of Enterprises (SAFE) (Analytical Report). European Commission.

Duff, V. (2019, February 19). Importance of finance \& its role within business. Small business. https://smallbusiness.chron.com/ importance-finance-its-role-within-business-1513.html 
Erskine, R., \& Yong, J. (2020, January 6). Performance and financial management: key factors for small and medium-sized entities' survival in a volatile environment. International Federation of Accountants. https://www.ifac.org/knowledge-gateway/ contributing-global-economy/discussion/performance-and-financial-management-key-factors-small-and-medium-sized-entities-survival-volatile

European Commission. (2003). Commission Recommendation of 6 May 2003 concerning the definition of micro, small and medium-sized enterprises (Text with EEA relevance) (notified under document number C(2003) 1422). Official Journal L, 124, 36-41.

Harelimana, J. B. (2017). Role of access to finance for the performance of small and medium enterprises in Muhoza sector, Rwanda. Business and Economics Journal, 8(1), 1000279. https://doi.org/10.18535/afmj/v2i1.02

Hartšenko, J., \& Sauga, A. (2013). The role of financial support in SME and economic development in Estonia. Business and Economic Horizons, 9(2), 10-22. https://doi.org/10.15208/beh.2013.6

Hartungi, R. (2007). Understanding the success factors of micro-finance institution in a developing country. International Journal of Social Economics, 34(6), 388-401. https://doi.org/10.1108/03068290710751803

Herr, H., \& Nettekoven, Z. M. (2017). The role of small and medium-sized enterprises in developmentwhat can be learned from the German experience? Friedrich Ebert Stifftung.

Martinez, L. B., Guercio, M. B., \& Bariviera, A. F. (2020). A meta-analysis of SMEs literature based on the survey on access to finance of enterprises of the European central bank. International Journal of Finance \& Economics. https://doi.org/10.1002/ijfe.2247

McGuinnessa, G., Hogana, T., \& Powell, R. (2018). European trade credit use and SME survival. Journal of Corporate Finance, 49, 81-103. https://doi.org/10.1016/j.jcorpfin.2017.12.005

Moritz, A., Block, J. H., \& Heinz, A. (2016). Financing patterns of European SMEs - an empirical taxonomy. Venture Capital, 18(2), 115-148. https://doi.org/10.1080/13691066.2016.1145900

Moya-Martinez, P., \& Pozo-Rubio, P. D. (2020). The financing of SMEs in the Spanish tourism sector at the onset of the 2008 financial crisis: lessons to learn? Tourism Economics. https://doi.org/10.1177/1354816620921958

Organisation for Economic Co-operation and Development. (2017, June 7-8). Enhancing the contributions of SMEs in a global and digitalised economy (Meeting of the OECD Council at Ministerial level). Paris. https://www.oecd.org/industry/C-MIN2017-8-EN.pdf

Organisation for Economic Co-operation and Development. (2020). Financing SMEs and entrepreneurs 2020: An OECD Scoreboard. OECD Publishing. https://doi.org/10.1787/061fe03d-en

Park, S., Lee, I. H., \& Kim, J. E. (2020). Government support and small- and medium-sized enterprise (SME) performance: the moderating effects of diagnostic and support services. Asian Business and Management, 19, 213-238. https://doi.org/10.1057/s41291-019-00061-7

Pergelova, A., \& Angulo-Ruiz, F. (2014). The impact of government financial support on the performance of new firms: the role of competitive advantage as an intermediate outcome. Entrepreneurship \& Regional Development, 26(9-10), 669-705. https://doi.org/10.1080/08985626.2014.980757

Peter, F. O., Adegbuyi, O., Olokundun, M. A., Peter, A. O., Amaihian, A. B., \& Ibidunni, S. A. (2018). Government financial support and financial performance of SMEs. Academy of Strategic Management Journal, 17(3), 1-10.

Prijadi, R., Wulandari, P., Desiana, P. M., Pinagara, F. A., \& Novita, M. (2020). Financing needs of micro-enterprises along their evolution. International Journal of Ethics and Systems, 36(2), 263-284. https://doi.org/10.1108/IJOES-05-2018-0071

Prohorovs, A., \& Beizitere, I. (2015). Trends, sources and amounts of financing for micro-enterprises in Latvia. Procedia - Social and Behavioral Sciences, 213(1), 404-410. https://oi.org/10.1016/j.sbspro.2015.11.558

Raudeliūnienė, J., Tvaronavičienė, M., Dzemyda, I., \& Sepehri, M. (2014). Sustainable entrepreneurship through energy stewardship: role of values and behavioral patterns. Entrepreneurship and Sustainability Issues, 2(2), 107-117. https://doi.org/10.9770/jesi.2014.2.2(6)

Rouf, A. K. (2012). Green microfinance promoting green enterprise development. Humanomics, 28(2), 148-161. https://doi.org/10.1108/08288661211228906

Rungani, E. C., \& Potgieter, M. (2018). The impact of financial support on the success of small, medium and micro enterprises in the Eastern Cape province. Acta Comercii, 18(1), 1-10. https://doi.org/10.4102/ac.v18i1.591

Rupeika-Apoga, R., \& Saksonova, S. (2018). SMEs' alternative financing: the case of Latvia. European Research Studies Journal, 21(3), 43-52. https://doi.org/10.35808/ersj/1042

Rupeika-Apoga, R., \& Solovjova, I. (2016). Profiles of SMEs as borrowers: case of Latvia. In Contemporary issues in finance: current challenges from across Europe (Vol. 98, pp. 63-76). Emerald Group Publishing Limited. https://doi.org/10.1108/S1569-375920160000098005

Saksonova, S., \& Papiashvili, T. (2021). Micro and small businesses access to finance and financial literacy of their owners: evidence from Latvia, Estonia and Georgia. In I. Kabashkin, I. Yatskiv, \& O. Prentkovskis (Eds.), Lecture notes in networks and systems: Vol 195. RelStat 2020: Reliability and statistics in transportation and communication (pp. 667-677). Springer. https://doi.org/10.1007/978-3-030-68476-1_62

Small Business Administration. (2018). Frequently asked questions. About small business. U.S. Small Business Administraition. https://www.sba.gov/sites/default/files/advocacy/Frequently-Asked-Questions-Small-Business-2018.pdf

Verovska, L., \& Zujeva, R. (2019). The role of small business in the economy and methods of its government support using the example of the Republic of Latvia. Economics and Culture, 16(2), 72-81. https://doi.org/10.2478/jec-2019-0023

World Trade Organization. (2016). World Trade Report 2016. Levelling the trading field for SMEs. https://doi.org/10.30875/4348b814-en 